\title{
Incest and Sexual Assualt on Minor Girls
}

\author{
Dr. Geetika Sood, Avrida Jan \\ LL.M, Chandigarh University, Mohali, Punjab, India
}

\begin{abstract}
How to cite this paper: Dr. Geetika Sood | Avrida Jan "Incest and Sexual Assualt on Minor Girls" Published in International Journal of Trend in Scientific Research and Development (ijtsrd), ISSN: 24566470, Volume-3 | Issue-4, June 2019, pp.177-180, URL: https://www.ijtsrd.c om/papers/ijtsrd23 608.pdf

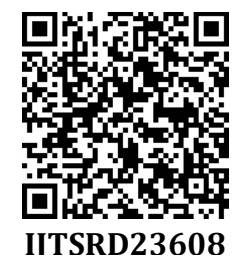

Copyright (C) 2019 by author(s) and International Journal of Trend in Scientific Research and Development Journal. This is an Open Access article distributed under the terms of the Creative Commons

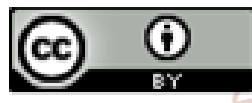
Attribution License (CC BY 4.0) (http://creativecommons.org/licenses/ by/4.0)

\section{INTRODUCTION}

One common form of sexual abuse of children is incest, which has been defined as sexual contact that occurs between family members. * Most incest occurs between older male relatives and younger female children in families of every class and color. Other instances of sexual abuse of children are most often committed by friends who have access to children within the family setting and by people normally trusted by parents: doctors, dentists, teachers, and baby-sitters.

The first of such offence came across and repotted and officially was that of kallu V. State of Andhra Pradesh ${ }^{2}$ where the father raped his minor daughter of 13 years old. Similar other cases like Radhya Sham V. State of J\& $K^{3}$, Abdul Wahid V. State of Maharashtra ${ }^{4}$ have reported incestuous relation of elderly males usually the father commits the offence with their minor daughters only. In case of Madan lal V. State of $M P^{5}$ father in law raped her daughter in law.

A sexually abusive relationship is one over which a child or young woman has no control. A trusted family member or friend uses his power, as well as a child's love and dependence, to initiate sexual contact and often to ensure that the relationship continues and remains secret.

${ }^{1}$ National Crime Research \& Bureau, Ministry of Home Affairs.

21980 Cr.L.J. 1380 (Bombay HC)

320123 SCC 443.

41993 Cr.L.J 997

51999 Cr R 5421997 (2) crimes 210
Despite the fact that children are more likely to be sexually abused by an adult they know, parents teach children to expect danger from strangers and not from trusted authority figures. It is understandable, given this fact, that a violation of this trust is so terribly frightening and confusing.

The extent of incest and childhood sexual abuse is difficult to measure because of lack of reporting and lack of memory. One study in which adults were asked to report on past incidents found that one in four girls and one in ten boys experienced sexual abuse.

Incest and sexual abuse of children take many forms and may include sexually suggestive language; prolonged kissing, looking, and petting; vaginal and/or anal intercourse; and oral sex. Because sexual contact is often achieved without overt physical force, there may be no obvious signs of physical harm.

Whether or not the signs of abuse are physical and obvious, sexual abuse in childhood can have lifelong consequences. As survivors, we often blame ourselves long after the abuse has ended--for not saying no, for not fighting back, for telling or not telling, for having been "seductive," for having trusted the abuser. Often there is no one to confirm that someone treated us cruelly and that this abuse was devastating to us. It is often very difficult to talk about incest or childhood sexual abuse. Some of us may never have told anyone, though the abuse may have continued for years. We may have dreaded family gatherings, where a particular uncle or 
family friend would come after us. For some of us, exploring our bodies with an older brother turned into a sexual encounter, after which we found ourselves feeling we had been taken advantage of. Sometimes a father, uncle, or teacher abused our sisters, and we didn't find out for years. Every survivor has her own story, and every story is valid. ${ }^{6}$

\section{SEXUAL ASSUALT ON MINOR GIRLS}

Sections 7 and 8 POCSO Sexual assault and punishment: Two elements need to be present in an act in order to come within the ambit of this offence: physical contact without penetration and sexual intent.

The following acts by a person would qualify under section 7 POCSO:

1. Touching the vagina, penis, anus or breast of a child with sexual intent.

2. Making a child touch the vagina, penis, anus or breast of such person or any other person.

3. Doing any other act with sexual intent which involves physical contact without penetration. ${ }^{7}$

The punishment under section 8 POCSO for sexual assault is imprisonment from three years to five years and fine. ${ }^{8}$

Sections 9 and 10 POCSO Aggravated sexual assault and punishment:

When persons in certain positions of trust and responsibility commit the act of sexual assault, then aggravated punishment under sections 9 and 10 POCSO apply.

Those who come under this category of offenders are:

1. Police officers

2. Members of the armed forces/security forces

3. Public servants

4. The management/staff of a jail, remand home, protection home, observation home, other place of custody or care and protection

5. Member/staff of a hospital (government and private)

6. Member/staff of an educational institution or religious institution

7. Anyone, being a relative of the child through blood/adoption/marriage/guardianship/in foster care/domestic relationship with parent/living in same or shared household

8. Anyone who is in the ownership or management or staff of any institution providing services to the child

9. Anyone who is in a position of trust or authority of a child in an institution or home

10. Anyone who knows the child is pregnant and commits sexual assault on a child.

${ }^{6} \mathrm{http}: / /$ www.feminist.com/resources/ourbodies/viol_incest .html> accessed on $20^{\text {th }}$ march 2018

7 Section 7 POCSO. Sexual assault: Whoever, with sexual intent touches the vagina, penis, anus or breast of the child or makes the child touch the vagina, penis, anus or breast of such person or any other person, or does any other act with sexual intent which involves physical contact without penetration is said to commit sexual assault.

8Section 8 POCSO. Punishment for sexual assault: Whoever, commits sexual assault, shall be punished with imprisonment of either description for a term which shall not be less than three years but which may extend to five years, and shall also be liable to fine.
Certain types of acts qualify for aggravated punishment:

1. Committing gang sexual assault on a child

2. Using deadly weapons, fire, heated/corrosive substance for committing sexual assault on a child

3. Causing grievous hurt/bodily harm/injury to sex organs of child

4. Physically incapacitating a child

5. Causing a child to become mentally ill

6. Causing impairment of child temporarily or permanently

7. Making a female child pregnant

8. Inflicting a child with HIV or other life threatening disease

9. Committing sexual assault more than once or repeatedly on a child

10. Attempting to murder the child

11. Committing sexual assault on a child in the course of communal or sectarian violence

12. Committing sexual assault on a child when previously convicted of any offence under the POCSO or any sexual offence punishable under any other law for the time being in force

13. Committing sexual assault on a child and making the child to strip or parade naked in public.

When a child belongs to a certain category of victim, then committing sexual assault on such a child would qualify for the commission of the offence of aggravated penetrative sexual assault:

1. Mentally or physically disabled children

2. A child below twelve years of age. ${ }^{9}$

The punishment under section 10 POCSO for aggravated sexual assault is imprisonment for a term not less than five years up to seven years and fine. ${ }^{10}$

\section{AGE OF CONSENT}

In many jurisdictions, the age of consent is interpreted to mean mental or functional age. As a result, victims can be of any chronological age if their mental age makes them unable to consent to a sexual act. Other jurisdictions, such as Kentucky, eliminate the legal concept of "mental age" and treat sexting with a mentally incapacitated person as a specific crime. ${ }^{11}$

${ }^{9} 220$ Section 9 POCSO. Aggravated sexual assault: (a) Whoever, being a police officer, commits sexual assault on a child-

(i) within the limits of the police station or premises where he is appointed; or (ii) in the premises of any station house whether or not situated in the police station to which appointed; or (iii) in the course of his duties or otherwise; or (iv) where he is known as, or identified as a police officer; or (b) whoever, being a member of the armed forces or security forces, commits sexual assault on a child-

(i) within the limits of the area to which the person is deployed; or (ii) in any areas under the command of the security or armed forces; or (iii) in the course of his duties or otherwise; or (iv) where he is known or identified as a member of the security or armed forces;

${ }^{10}$ Section 10. Punishment for aggravated sexual assault.Whoever, commits aggravated sexual assault shall be punished with imprisonment of either description for a term which shall not be less than five years but which may extend to seven years, and shall also be liable to fine.

${ }^{11}$ https://en.wikipedia.org/wiki/Statutory_rape 
Age of consent refers to the age at which a person is considered to be capable of legally giving informed consent to sexual acts with another person.

Before this law was passed, the age of consent was considered to be 16 years (except if the woman was married to the accused, in which case it may be lower). Section 375 of the Indian Penal Code, 1860 states that any sexual intercourse with a woman who is below the age of 16 years is considered to be "rape". The consent of the person is irrelevant.

In the case of Umesh V. State of Karnataka ${ }^{12}$ a school certificate was not a conclusive evidence of the age of prosecutrix and the ossification test also gave only an approximate age, which may be 2 years on either side. It was held that medical evidence can be ignored if there is any other reliable evidence contrary to that.

In the case of Dayachand V. Sahib Singh ${ }^{13}$ the correct date of birth is never disclosed in the school admission register. The court has to rely on and base its conclusion upon all the facts and circumstances disclosed an examination of all the physical features of the person whose age is in question in conjunction with such oral testimony as may be available.

This post provides a snapshot of the key provisions of the Act, the debate surrounding the controversial provision and a comparison of the related law in other countries.

\section{Key provisions of the Act}

The Act defines a child as any person below the age of 18 years and provides protection to all children from offences such as sexual assault, penetrative sexual assault and sexual harassment. It also penalizes a person for using a child for pornographic purposes.

The Act states that a person commits "sexual assault" if he touches the vagina, penis, anus or breast of a child with sexual intent without penetration.

The Act treats an offence as "aggravated" if it is committed by a person in a position of authority or trust such as a member of the security forces, a police officer or a public servant.

It specifies penalties for the offences and provides a mechanism for reporting and trial of such offences.

\section{Debate over the age of consent}

After introduction, the Bill was referred to the Standing Committee on Human Resource Development. The Committee submitted its report on December 21, 2011

Taking into account the recommendations of the Standing Committee, the Parliament decided to amend certain provisions of the Bill before passing it.

The Bill stated that if a person is accused of "sexual assault" or "penetrative sexual assault" of a child between 16 and 18 years of age, it would be considered whether the consent of the child was taken by the accused. This provision was deleted from the Bill that was passed.
The Bill (as passed) states that any person below the age of 18 years shall be considered a child. It prohibits a person from engaging in any type of sexual activity with a child. However, the implication of this law is not clear in cases where both parties are below 18 years. The increase in the age of consent to 18 years sparked a debate among experts and activists.

Proponents of increasing the age of consent argued that if a victim is between 16 and 18 years of age, the focus of a sexual assault case would be on proving whether he or she consented to the act or not. The entire trial process including cross-examination of the victim would focus on the conduct of the victim rather than that of the accused .

Opponents of increasing the age of consent pointed out that since this Act criminalizes any sexual activity with persons under the age of 18 years (even if consensual), the police may misuse it to harass young couples or parents may use this law to control older children's sexual behavior.

\section{International comparison}

In most countries, the age of consent varies between 13 and 18 years. The table below lists the age of consent and the corresponding law in some selected countries. ${ }^{14}$

\begin{tabular}{|c|c|c|}
\hline Countries & Age of consent & Law \\
\hline $\begin{array}{l}\text { Dous } \\
\text { undific } \\
\text { and }\end{array}$ & $\begin{array}{l}\text { Varies from state to state } \\
\text { between } 16 \text { and } 18 \text { years. } \\
\text { In some states, the } \\
\text { difference in age between } \\
\text { the two parties is taken } \\
\text { into account. This can } \\
\text { vary between } 2-4 \text { years. }\end{array}$ & $\begin{array}{l}\text { Different } \\
\text { state laws }\end{array}$ \\
\hline UK & 8 & $\begin{array}{c}\text { Sexual } \\
\text { Offences } \\
\text { Act, } 2003\end{array}$ \\
\hline Germany & $\begin{array}{l}14 \text { years (16 years if the } \\
\text { accused is a person } \\
\text { responsible for the child's } \\
\text { upbringing, education or } \\
\text { care). }\end{array}$ & $\begin{array}{c}\text { German } \\
\text { Criminal } \\
\text { Code }\end{array}$ \\
\hline France & 15 years & $\begin{array}{l}\text { French } \\
\text { Criminal } \\
\text { Code }\end{array}$ \\
\hline Sweden & $\begin{array}{l}15 \text { years (18 years if the } \\
\text { child is the accused } \\
\text { person's offspring or he is } \\
\text { responsible for upbringing } \\
\text { of the child). }\end{array}$ & $\begin{array}{c}\text { Swedish } \\
\text { Penal Code }\end{array}$ \\
\hline Malaysia & $\begin{array}{l}16 \text { years for both males } \\
\text { and females. }\end{array}$ & $\begin{array}{c}\text { Malaysian } \\
\text { Penal Code; } \\
\text { Child Act } \\
2001 \\
\end{array}$ \\
\hline China & $\begin{array}{c}\text { No information about } \\
\text { consent. Sex with a girl } \\
\text { below } 14 \text { years is } \\
\text { considered rape. Sodomy } \\
\text { of a child (male or female) } \\
\text { below } 14 \text { years is an } \\
\text { offence. }\end{array}$ & $\begin{array}{c}\text { Criminal } \\
\text { Law of } \\
\text { China, } 1997\end{array}$ \\
\hline
\end{tabular}

${ }^{14}$ http://www.prsindia.org/theprsblog/?p=1680
12 (2011) 3 SCC 85

13 (2011) 8 SCC 567

d


International Journal of Trend in Scientific Research and Development (IJTSRD) @ www.ijtsrd.com eISSN: 2456-6470

\begin{tabular}{|c|c|c|}
\hline Canada & 16 years & $\begin{array}{c}\text { Criminal } \\
\text { Code of } \\
\text { Canada }\end{array}$ \\
\hline Brazil & 14 years & $\begin{array}{c}\text { Brazilian } \\
\text { Penal Code } \\
2009\end{array}$ \\
\hline Australia & $\begin{array}{l}\text { Varies between } 16 \text { and } 17 \\
\text { years among different } \\
\text { states and territorial } \\
\text { jurisdictions. In two } \\
\text { states, a person may } \\
\text { engage in sexual activity } \\
\text { with a minor if he is two } \\
\text { years older than the child. } \\
\text { In such cases the child has } \\
\text { to be at least } 10 \text { years old. }\end{array}$ & $\begin{array}{c}\text { Australian } \\
\text { Criminal } \\
\text { laws }\end{array}$ \\
\hline India & 18 years. & $\begin{array}{c}\text { Protection } \\
\text { of Children } \\
\text { Against } \\
\text { Sexual } \\
\text { Offences } \\
\text { Act, } 2012 \\
\end{array}$ \\
\hline
\end{tabular}

\section{SUGGESTIONS}

1. Moral and sex education should be made compulsory at school and college level in order to prevent crime against women in general and female children in particular.

2. Pornographic literature and films depicting crime, sex and violence should be banned for preventing sexual offences against the female child.

3. The social attitudes towards the girl child should be changed to build a healthy society.

4. The Earning capacity of women should be improved and their economic status should be raised. This will automatically lead to the upliftment of the girl child.

5. Efforts should be made through education and other measures to change the attitude of the community that carries the centuries old bias against the girl child, believing that the girl child is an expense, a waste and a burden.

6. A national debate needs to be initiated to create the necessary social climate in favour of the girl child on a warfooting

7. Child marriages should be prevented with greater responsibility. Persons who supply information to authorities about child marriages, foeticide, infanticide or other atrocities should be rewarded so that many more will come forward to give such information.

Child Sexual abuse is maybe one of the most exceedinglybad risks that India confronts today. Dissimilar to different manifestations of sexual misuse, we can't enjoy faulting the victimized person or other outer strengths (like the impact of Western society). Child sexual misuse tosses a mirror to the general public and demonstrates a face of humankind we are hesitant to see. The main way we can battle what we see in this mirror is by first looking the issue straight in its eyes as opposed to brushing it far from anyone's regular field of vision.

Sexual misuse of child and child sexual ill-use are a portion of the minimum investigated manifestations of child Sexual abuse. Absence of sound strategies and pointers to direct far reaching exploration and to aggregate quantitative information frequently connected with issue of ill-use, abuse and disregard, restricts the accessibility of precise quantitative and subjective information. Lacking and inadequate lawful procurements and the unlucky deficiency of observing frameworks likewise hinder information accumulation.

Different national studies make pass that the issues of business sexual abuse of youngsters and child sexual abuses are across the board, and are obtaining disturbing extents. Various little scale studies, daily paper reports and contextual investigations from a few nations give understanding into the nature and gravity of this issue.

8. The substantial contribution made by the girl child in the household and national economy should be widely acknowledged.

9. Those women who have proved their ability in different spheres of life should be given publicity through media and through text books. This will help the girls to build up their confidence in themselves and have new role models.

10. Training programmes should be organized for government functionaries at the grassroots level to educate ad sensitise them on the issues relating to the girl child.

\section{REFERRENCE}

[1] http://www.prsindia.org

[2] https://en.wikipedia.org

[3] www.manupatra.com

[4] http://www.feminist.com/resources/ourbodies/viol_i ncest.html

[5] http://www.prsindia.org

[6] National Crime Research \& Bureau, Ministry of Home Affairs.

[7] Protection of Children from Sexual Offence Act, 2012

[8] Criminal Procedure code, 1975 